\title{
Pengaruh Kitosan Terhadap Jumlah Osteoklas dan Osteoblas Pada Tikus Galur Wistar Model Menopause
}

\author{
Muhammad Nur ${ }^{1}$ \\ ${ }^{1}$ Akper Pemkab Pamekasan Madura \\ Email : mnurfh@gmail.com
}

\begin{abstract}
ABSTRAK
Kitosan merupakan salah satu polimer yang melimpah dan tersebar di alam. Memiliki efek penyembuhan yang cepat bagi jaringan serta berpengaruh pada remodeling tulang. Tujuan penelitian ini untuk membuktikan bahwa pemberian kitosan mempengaruhi penurunan jumlah osteoklas dan peningkatan jumlah osteoblas pada tikus putih betina galur Wistar model menopaus yang dilakukan ovarektomi.Penelitian ini menggunakan rancangan posttest only control group design.Total sampel 30 ekor tikus dibagi menjadi tigakelompok secara acak, dibuat osteoporosis dengan model menopaus yangdilakukan ovarektomi pada kelompok kontrol positif dan kelompok perlakuan yang kemudian pada kelompok perlakuan diberi ektrak kitosan dosis tunggal $45 \mathrm{mg} / \mathrm{hari}$ melalui sonde / Nasogastric Tube(NGT). K1 merupakan kelompok kontrol negatif (tanpa dilakukan ovarektomi dan tanpa kitosan), K2 merupakan kelompok kontrol positif (dengan ovarektomi tanpa kitosan), K3 merupakan kelompok perlakuan (dengan dilakukan ovarektomi dan pemberian kitosan $45 \mathrm{mg} / \mathrm{hari}$ ). Hasil penelitian menunjukkan terdapat perbedaan bermakna pada jumlah osteoblas antara K1 dengan K3, K2 dengan K3, dan perbedaan tidak bermakna di temukan pada kelompok K1 dengan K2. Sedangkan pada jumlah osteoklas hasil penelitian menunjukkan terdapat perbedaan bermakna pada kelompok $\mathrm{K} 1$ dengan $\mathrm{K} 2$ dan perbedaan tidak bermakna ditemukanpada kelompokK1 dengan K3, K2 dengan K3.Kesimpulan pada penelitian ini menunjukkan pemberian kitosandosis $45 \mathrm{mg} /$ /hari dapat meningkatkan jumlah osteoblas secara bermakna pada tikus putih betina model menopaus dan menurunkan jumlah osteoklas yang dilakukan ovarektomi dengan pemberian kitosan.
\end{abstract}

Kata kunci: Kitosan, menopause, jumlah osteoklas, jumlah osteoblas

\begin{abstract}
Chitosan is one of the most abundant and dispersed polymers in nature. It has a rapid healing effect for tissues and has an effect on bone remodeling. The purpose of this study was to prove that giving chitosan influenced the decrease of osteoclast number and increasing number of osteoblasts in female mice of wistar strain of ovariectomy menopause model.This study used a posttest only control group design. The total sample of 30 rats divided into three groups was randomized, osteoporosis was made with the menopausal model which was performed ovariectomy in the positive control group and the treatment group then in the treatment group was given chitosan extract of single dose of $45 \mathrm{mg} /$ day via Nasogastric Tube (NGT). K1 was a negative control group (without ovariectomy and without chitosan), K2 was a positive control group (with no chitosan ovariectomy), K3 was the treatment group (ovariectomy and chitosan $45 \mathrm{mg} /$ day). The results showed significant differences in the number of osteoblasts between $\mathrm{K} 1$ and $\mathrm{K} 3, \mathrm{~K} 2$ with $\mathrm{K} 3$, and no significant differences were found in the K1 group with K2. While the number of osteoclasts showed that there were significant differences in $\mathrm{K} 1$ group with $\mathrm{K} 2$ and no significant difference was found in $\mathrm{K} 1$ group with $\mathrm{K} 3$, K2 with K3.Conclusions in this study showed that $45 \mathrm{mg}$ / day of chitosan doses could significantly increase osteoblast counts in menopause female white rats and decrease the number of osteoclasts performed by ovariectomy with chitosan administration.
\end{abstract}

Keywords : Chitosan, Menopause, Osteoclast number, Osteoblast number 


\section{PENDAHULUAN}

Defisiensi estrogen pada pascamenopaus merupakan faktor terpenting penyebab peningkatan ketidakseimbangan remodeling tulang [1,2]. Kondisi ini menimbulkan perubahan keseimbangan aktivitas sitokin proinflamasi yang mengakibatkan resorpsi tulang [3] serta gangguan fungsi osteoblas akibat termostat hemostasis tulang yang menjadi tidak responsip terhadap stimulasi pembedahan mekanik sehingga terjadi penurunan pembentukan tulang $[4,5]$. Percobaan in vivo pada tikus galur wistar dengan ovarektomi menunjukan jumlah dan fungsi Era KO (estrogen reseptor alpha knock out).Hal ini menunjukan pengurangan massa tulang akibat pascaovarektomi atau menopause yang diawali oleh menurunya sel osteoblas dan meningkatnya sel osteoklas. [6], mengungkapkan bahwa kitosan mampu menekan proses osteoklastogenesis. Hasil penelitian Salma dan [7] menunjukkan pemberian kitosan $200 \mathrm{mg} /$ hari selama 30 hari pada cavia cobayameningkatkan jumlah sel osteoblas dan menurunkan jumlah sel osteoklas pada tulang alveolar.

Sampai saat ini pilihan pertama untuk pencegahan dan pengobatan ketidakseimbangan resorpsi dan formasi tulang adalah terapi sulih hormon (TSH) estrogen.Namun penggunaan TSH estrogen sintetik dapat menimbulkan efek samping baik subjektif maupun objektif, serta risiko kanker payudara danendometrium. Selain diperlukan pemantauan yangcermat saat terapi maupun pascaterapi, harga jual sediaan hormon estrogen relatif mahal untuk pemakaian jangka panjang.Maka perlu dicari alternatif lain yang dapat memenuhi kritria efektif, murah, alami (herbal), aman dan dapat diterima oleh wanita menopause.Konsep back to nature saat ini sangat populer di seluruh dunia, termasuk dalam dunia kedokteran.Pengobatan alternatif yang berasal dari alam berkembang sangat pesat.Dewasa ini pemanfaatan bahan alam menjadi fokus penelitian untuk pengobatan yang diharapkan mampu menjadi solusi alternatif bagi berbagai penyakit, diantaranya adalah pemanfaatan bahan aktif yang terdapat pada ekstrak cangkang udang yang didalamnya terkandung kitosan.

Kitosan merupakan salah satu polimer yang melimpah dan tersebar di alam.Memiliki efek penyembuhan yang cepat bagi jaringan serta berpengaruh pada remodeling tulang [8]. Kitosan adalah polisakarida dengan berat molekul besar yang dihubungkan oleh ikatan $\beta-1,4$ glikosida dan tersusun atas $\mathrm{N}$-asetil-glukosamin dan glukosamin [9]. Struktur kitosan memiliki gugus $-\mathrm{OH}$ dan $-\mathrm{NH}_{2}$ yang dapat menghasilkan ikatan hidrogen intra dan intermolekul [10] sehingga menyebabkan kitosan tidak larut dalam air. Gugus-gugus kitosan tersebut dapat berinteraksi atau berikatan kovalen dan menjadi landasan teknik drug 
delivery [11]. Penggunaan kitosan sebagaidrug delivery sudah banyak dilakukan dalam bidang medis seperti drug delivery insulin dan antikanker [12]. Kitosan mempunyai kemampuan mengikat, sehingga dapat juga diaplikasikan pada senyawa bukan obat yaitu antioksidan asam askorbat. [13], melaporkan bahwa kitosan dapat meningkatkan sintesiskolagen tipe I pada tahap awal, dan memfasilitasi diferensiasi sel-sel osteogenik pada percobaan in vitro fibroblas ligament periodontal manusia. Kitosan diketahui dapat mempercepat migrasi sel serta membantu pematangan jaringan.Secara invitro, kemampuan kitosan untuk mendukung adhesi sel dan mempengaruhi diferensiasi sel osteogenik adalah sifat klimia yang membuat kitosan dapat digunakan untuk regenerasi sel tulang. Secara in vivo, penelitian menunjukan bahwa implan membran kitosan pada kranial kucing mampu menstimulasi atau memberikan efek pada sel stroma disekeliling jaringan. Kitosan juga digunakan carrier growth factors untuk meningkatkan pembentukan tulang pada calvaria tikus [12]. Pada penelitian ini, pengaruh antiosteoporosis dari kitosan diberikan secara oral (personde) dikaji pada tikus putih betina yang dibuat menopaus agar mendapatkan keaaadaan osteoporosis dengan melakukan ovarektotomi.

Penelitian pada tikus post ovarektomi yang diberikan kitosan dengan dosis tunggal 45 $\mathrm{mg} /$ BBtikus/hari membuktikan terjadinya penurunan jumlah osteoklas dan peningkatan jumlah osteoblas. Berkaitan dengan sifat biologis kitosan yang unggul, seperti biokompatibilitas, mudah terdegradasi tanpa meninggalkan racun, tidak karsinogenik, serta memiliki efek anti bacterial dan efek penyembuhan yang cepat bagi jaringan. [13], melaporkan bahwa kitosan dapat meningkatkan sintesiskolagen tipe I pada tahap awal, dan memfasilitasi diferensiasi sel-sel osteogenik pada percobaan in vitro fibroblas ligament periodontal manusia. Yang diketahui dapat mempercepat migrasi sel serta membantu pematangan jaringan. Tujuan penelitian ini adalah untuk menentukan apakah pemberian kitosan meningkatkan jumlah osteoblas dan menurunkan jumlah osteoklas pada tikus yang dilakukan ovarektomi sebagai model menopause.

\section{TINJAUAN PUSTAKA}

\section{Kitosan}

Kitosan merupakan senyawa amino polisakarida rantai lurus tersusun oleh monomer glukosamin (poli-1,4-Dglukosamine) yang terhubung melalui ikatan (1-4) $\beta$-glikosidik, yang berasal dari kitin yang telah dideasetilasi. Kitosan merupakan biopolymer yang diperoleh dari deasetilasi kitin.Akhir-akhir ini kitosan sering diaplikasikan sebagai bahan multiguna karena mudah didapat dan bersifat biodegradable. Kitosan diperoleh dari deasetilasi chitin melalui 
proses kimia menggunakan enzim chitin diacetilase. Dalam penelitian ini kitosan didapat dari ekstrak cangkang udang yang produksi bank jaringan rumah sakit Dr. Soetomo Surabaya mengandung protein (25-40\%), kitin (15-20\%) dan kalsium karbonat (45-50\%) [14].

\section{Sifat Kitosan}

Kitosan adalah polisakarida dengan berat molekul besar yang dihubungkan oleh ikatan $\beta-1,4$ glikosida dan tersusun atas $\mathrm{N}$-asetil-glukosamin dan glukosamin [15]. Struktur kitosan memiliki gugus $-\mathrm{OH}$ dan $-\mathrm{NH}_{2}$ yang dapat menghasilkan ikatan hidrogen intra dan intermolekul [16] sehingga menyebabkan kitosan tidak larut dalam air. Gugus-gugus kitosan tersebut dapat berinteraksi atau berikatan kovalen dan menjadi landasan teknik drug delivery [17]. Penggunaan kitosan sebagai drug delivery sudah banyak dilakukan dalam bidang medis seperti drug delivery insulin dan antikanker [18]. Kitosan mempunyai kemampuan mengikat, sehingga dapat juga diaplikasikan pada senyawa bukan obat yaitu antioksidan asam askorbat.Sifat alami kitosan diklasifikasikan menjadi sifat biologi dan sifatkimia.Gugus amino yang dimiliki kitosan lebih banyak dibandingkan chitinsehingga kitosan lebih bersifat basa dan nukleofilik.kitosan tidak larut dalam air dan beberapa pelarut organik seperti dimetilsufoksida, dimetilformanida, pelarut alkohol dan piridin. kitosan larut dalam asam organik/mineral encer melalui protonasi gugus amino bebas pada $\mathrm{pH}$ kurang dari 6,5. Kitosan larut dengan baik pada asam format, asam asetat dan asam glutamate. Kelarutan kitosanakan menurun dengan bertambahnya berat molekul kitosan [19]. Ikatan hydrogen intermolekuler maupun intramolekuler pada kitosan lebih rendah dibandingkan chitin sehingga kitosan lebih mudah diaplikasikan dalam beberapa reagen dan mudah dibentuk menjadi spons, larutan, gel, pasta, membran, dan serat.

Sifat biologi kitosan antara lain, kitosan bersifat biokompatibel yang tidak beracun, tidak dapat dicerna juga mudah diuraikan oleh mikroba. Menurut [19], bahwa kitosan bersifat kationik, nontoksis, biodegradable, dan biokompatibel.Kitosan dapat berikatan dengan sel mamalia dan sel mikroba secara agresif dan mampu meningkatkan pembentukan tulang, serta menunjukkan aktvitas antibiotik melawan bakteri dan jamur.

\section{Manfaat Kitosan}

Berdasarkan karakteristik kitosan yang biodegradable dan biocompatible, manifestasi penggunaan kitosan telah banyak dilakukan. Dalam bidang pertanian, tanaman yang diberikan kitosanakan memiliki ketahanan yang kuat terhadap jamur. Dalam bidang bioteknologi, kitosan berperan dalam imobilisasi enzim, pemisahan protein dan regenerasi sel. Dalam industry makanan, kitosan digunakan sebagai antioksidan, pengawet alami dan 
penyerap warna.Kitosan juga dimanfaatkan sebagai adsorben logam dan kerap kali digunakan dalam program diet karena dapat menurunkan kolesterol [19].

Berkaitan dengan sifat biologis kitosan yang unggul, seperti biokompatibilitas, mudah terdegradasi tanpa meninggalkan racun, tidak karsinogenik, serta memiliki efek anti bacterial dan efek penyembuhan yang cepat bagi jaringan. [20], melaporkan bahwa kitosan dapat meningkatkan sintesiskolagen tipe I pada tahap awal, dan memfasilitasi diferensiasi sel-sel osteogenik pada percobaan in vitro fibroblas ligament periodontal manusia. Kitosan diketahui dapat mempercepat migrasi sel serta membantu pematangan jaringan.

Secara invitro, kemampuan kitosan untuk mendukung adhesi sel dan mempengaruhi diferensiasi sel osteogenik adalah sifat klimia yang membuat kitosan dapat digunakan untuk regenerasi sel tulang.Secara in vivo, penelitian menunjukan bahwa implan membran kitosan pada kranial kucing mampu menstimulasi atau memberikan efek pada sel stroma disekeliling jaringan. Kitosan juga digunakan carrier growth factors untuk meningkatkan pembentukan tulang pada calvaria tikus [21].

\section{Osteoporosis}

Osteoporosis berasal dari bahasan Yunani, osteo berarti tulang dan porosis berarti penuh rongga [22]. Menurut [23], osteporosis adalah penyakit tulang sistemik yang ditandai penurunan densitas massa tulang dan perburukan mikroarsitektur tulang sehingga tulang menjadi rapuh dan mudah patah. [24], mengemukakan penurunan densitas massa tulang disebabkan oleh ketidakseimbangan antara resorpsi tulang dan pembekuan tulang.

\section{Histologi Osteoblas}

Pada sel osteoblas manusia dan binatang, IL-6 menunjukkan efek antiapoptotik, in vitro menunjukkan antagonis efek proapoptotik dari glukokortikoid [25]. Estrogen juga mempunyai efek inhibisi apoptosis osteoblas dan osteosit sehingga berperan dalam control masa hidup kedua sel tersebut [26]. Estrogen melalui jalur instrinsik (mithocondrial pathway) meningkatkan produksi anti apoptotic protein seperti $\mathrm{Bclz}$ dan $\mathrm{Bcl} \mathrm{x}$ dan penurunan preapoptotic protein seperti $\mathrm{Bak}$, Bax dan $\mathrm{Bcm}$. Peningkatan $\mathrm{Bcl} \mathrm{z}$ dan $\mathrm{Bcl} \mathrm{x}$ menghambat pengeluaran cytochrom $c$ dari mitokondria sehingga tidak terjadi kompleks cytochrome $c$ dan Apaf-1 (apoptosis activating factor-1), disamping $\mathrm{Bcl} \mathrm{z}$ dan $\mathrm{Bcl}$ x juga menginhibisi Apaf-1. Protein lain yang dihambat pengeluarannya dari mitokondria adalah AIF (apoptosis inducing factor) sehingga tidak terjadi ikatan dan netralisir inhibitor apoptosis. Hasil akhir dari fase 
inisiasi ini adalah hambatan caspase cascade sehingga tidak berlanjut dengan fase aksekusi sel [27].

\section{Histologi Osteoklas}

Osteoklas

merupakan sel multinuklear yang jauh lebih besar jika dibanding dengan sel-sel tulang lainya.Ukuran osteoklas berkisar antara 20um - 100um dengan jumlah inti mencapai 50 buah.Osteoklas berasal dari diferansiasi monosit/makrofag yang terdapat ditulang dan mensekresi berbagai asam dan ezim yang mencerna tulang dan memudahkan fagositosisnya.Osteoklas hanya terdapat pada satu bagian kecil tulang pada satu waktu dan memfagosit tulang sedikit demi sedikit, kemudian osteoklas menghilang dan digantikan oleh osteoblas untuk menghasilkan tulang yang baru [28]. Osteoklas terbentuk dari sel precursor berupa stem sel hematopoetik yang disebut monosit. Osteoklas mengabsorbsi tulang dengan cara menempel pada permukaan tulang dan menurunkan $\mathrm{pH}$ sekitar sehingga mencapai kadar asam sekitar 4,5. Mineral tulang menjadi larut dan kolagen menjad elektroni pecah.Diferensiasi dan fungsi osteoklas terutama diatur beberapa factor yaitu Macrophage Colony-Stimulating Factor (M-CSF), Receptor for Activation of Nuclear Factor Kappa 8 Ligand (RANKL), dan Osteoprotogerin (OPG) [29].

Osteoklas adalah sel multinukler yang terdiri dari banyak mitokondria, lisosom dan ribosom dengan morfologi bentuk tepi membrane berkerut karena invaginasi plasma membran (ruffled border). Osteoklas juga dilengkapi area yang disebut clear zone yang terdiri dari berkas actin-likefilament yang berfungsi untuk mutup area yang akan diresorpsi. Vacuolar $H^{+}$ATPase atau ATP-driven proton pump yang terletak ditepi membran menyebabkan area bersifat asam sehingga melarutkan komponen mineral matriks tulang. Sekresi metrix metalloproteinase (MMP), kolagenase dan gelatinase serta cathepsin $K, B$ dan $L$ (suatu lysosomal cysteine proteinase ) menyebabkan degradasi komponen protein matriks tulang terutama kolagen [30].

Osteoklas membentuk enzim phsphohydrolase dan tartrate-resistant acid phosphatase (TRAPase).Enzim TRAPase dilepas kedalam lakuna tempat resorpsi tulang pada saat pembongkaran tulang, diduga berperan untuk melarutkan mineral matriks tulang. Pada saat pembongkaran tulang, osteoklas juga melepas collagen crosslink hasil degradasi matriks

protein (kolagen tipe1) seperti pyridinium crosslink (free pyridinoline dan deoxypyridinoline),cross-linked telopeptide( $N$-telopeptidesdan $C$-telopeptides ) disamping 
enzim TRAP dan kalsium, sebagai subtansi petanda biokimiawi resorpsi atau pembongkaran tulang $[31,32]$.

\section{Patofisiologi Osteoporosis}

Menurut [33], osteoporosispada dasarnyadisebabkan olehpenyimpangandalam remodeling tulangyang menyebabkan kerapuhantulang. Dalam proses remodeling tulang, sel stroma dan osteoblas menyintesis dan menjumlahkan pada membrane selnya suatu anggota family Necrosis Tumor Factor (TNF) yang disebut ligan RANK. Ligan RANK berikatan dengan suatu molekul reseptor yang dikenal dengan singkatan RANK (receptor activator for nuclear factor $k \mathrm{~B}$ ) yang dijumlahkan oleh makrofag. Diferensiasi makrofag menjadi osteoklas mengisyaratkan bahwa ligan RANK berikatan dengan reseptor RANK di makrofag. Selain itu, sel stroma juga menghasilkan sitokin yang disebut macrophage colony-stimulating factor yang melekat ke reseptor khusus di makrofag. Ligan RANK dan macrophage colonystimulating factor bekerja bersama-samamengubah makrofag menjadi osteoklas yang meresorbsi tulang.

Aktivitas osteoklastogenik dijalur ligan RANK-RANK di atur oleh molekul yang disebut osteoprotegerin (OPG) yang juga diekskresi sel stroma/osteoblas. OPG adalah suatu reseptor pengikat yang dapat mengikat ligan RANK sehingga tidak dapat berikatan dengan reseptor RANK. Jika ligan RANK berikatan dengan OPG dan bukan dengan reseptor RANK maka pembentukan osteoklas akan terganggu sehingga resorbsi tulang menurun.

Factor hormone berperan penting dalam timbulnya osteoporosis terutama pascamenopause. Estrogen dapat merangsang pembentukan OPG sehingga menghambat pembentukan osteoklas. Namun jika terjadi penurunan kadar estrogen akan menyebabkan peningkatan produksi IL-1, IL-6, dan Necrosis Tumor Factor (TNF) oleh monosit dan sumsum tulang lainnya. Sitokin ini yang akan meningkatkan jumlah precursor osteoklas seningga resorbsi tulang juga akan meningkat. Selain itu, beberapa penelitian mengisyaratkan bahwa defisiensi estrogen juga menyebabkan penurunan aktivitas osteoblastik sehingga pembentukan tulang baru juga menurun. Hal ini yang akan menjadi factor penurunan massa tulang sehingga terjadi osteoporosis.

\section{METODOLOGI PENELITIAN}

Penelitian ini bersifat eksperimental laboratorisdengan rancangan penelitian yang digunakan adalah true experimental melalui pendekatan ThePostest - Only ControlGroup Design.Adapun rancangan penelitian yang digunakan dalam penelitian ini adalah randomized 
post test only control group design.Penelitian ini telah dilakukan padabulan Mei sampai dengan agustus 2014 di Laboratorium Biokimia FK Unair Surabaya, RS Hewan, FKH Unair Surabaya.Subjek berupa tikus putih galurwistar (Rattus norvegicus L.) berjumlah30ekor. Penentuan besar sampel mengunakanrumus Federer [34] yaitu minimal 10 ekor tikus perkelompok.

\section{Alat dan Bahan Penelitian}

Alat-alat yang digunakan dalampenelitian ini: kandang, sarung tangan, tempatair minum dan makan hewan, alat-alat gelas(Pyrex), rotary evaporator, ayakan, jarumsuntik berujung Nasogastric tube (NGT) no.5dan no.3, disposible syringe 3ml, jarum suntik,gunting, 1. Bahan penelitian adalah Kitosan, Hewan yang digunakan dalam penelitian ini adalah tikus galur wistar putih (galur /wistar sebanyak 30 ekor, jenis kelaminbetina), berat badan 100 150 gram, umur $2-3$ bulan, tikus galur wistar ini dipelihara dengan kondisi yang sama selama 20hari agar dapat beradaptasi.

Bahan kimia : air kemasan, betadin, éter, ketamin, larutan formalin buffer 10\%, xylol (MERCK), gliserin, paraffin, larutan EDTA 10\%, solusi polyvinylpyrolidone 7,5\%, larutan Hematoxylin Eosin, alkohol 70\%; 80\%; 95\% dan 96\%, egg albumin, dan entelan (MERCK), HCL, aquades dan larutan PBS.Carboxy methylcellulosse $1 \%$ (CMC).

\section{HASIL}

Hasil penelitian menunjukkan terdapat perbedaan yang bermakna $(\mathrm{p}<0,05)$. Data deskriptif hasil penelitian untuk jumlah sel osteoblas dan jumlah sel osteoklas dapat dilihat pada Tabel 5.1 dan 5.2 berikut:

Tabel 5.1. Nilai rerata (mean) dan simpang baku (SD) sel osteoblas tikus pada kelompok $\mathrm{K} 1, \mathrm{~K} 2$, dan K3.

\begin{tabular}{|c|c|c|}
\hline Kelompok & $\mathbf{n}$ & Mean dan SD \\
\hline K1 & 10 & $115,60 \pm 32,108$ \\
K2 & 10 & $94,10 \pm 28,006$ \\
K3 & 10 & $149,73 \pm 29,247$ \\
\hline
\end{tabular}

Tabel 5.2. Nilai rerata (mean) dan simpang baku (SD) sel osteoklas tikus pada kelompok K1, $\mathrm{K} 2$, dan K3. 


\begin{tabular}{|c|c|c|}
\hline Kelompok & $\mathbf{n}$ & Mean dan SD \\
\hline K1 & 10 & $3,80 \pm 2,044$ \\
K2 & 10 & $11,50 \pm 5,740$ \\
K3 & 10 & $6,40 \pm 3,777$ \\
\hline
\end{tabular}

Hasil analisis deskriptif pada kelompok K3 sebagai kelompok perlakuan,didapatkan hasil peningkatan Osteoblas dengan mean $\pm \mathrm{SD}=149,50 \pm 29,247$ dibandingkan K2 sebagai kelompok kontrol positif mean $\pm \mathrm{SD}=94,10 \pm 28,006$, adapun hasil analisis deskriptif pada kelompok K3 sebagai kelompok perlakuan,didapatkan hasil penurunan Osteoklas dengan mean $\pm \mathrm{SD}=6,40 \pm 3,777$ dibandingkan $\mathrm{K} 2$ sebagai kelompok kontrol positif dengan mean $\pm \mathrm{SD}=11,50 \pm 5,740$, menunjukkan bahwa pemberian kitosan dengan dosis $45 \mathrm{mg} / \mathrm{hari}$ dosis tungal selama 10 hari berpengaruh pada tikus dengan post ovarektomi.

\section{DISKUSI}

Hasil penelitian yang ditunjukkan di atas merupakan nilai dari jumlah sel osteoblas dan jumlah sel osteoklasdari tiap kelompok penelitian. Pada kelompok kontrol positif menunjukkan hasil uji normalitas osteoklas yang paling besar $(0,523)$ yang berarti kelompok kontrol positif memiliki potensi pembentukan tulang yang paling kecil. Sedangkan pada kelompok perlakuan menunjukkan hasil uji normalitas osteoklas yang paling kecil $(0,457)$ .Hal ini menunjukkan bahwa pada kelompok perlakuan memiki potensi dalam pembentukan tulang yang paling besar. Hasil penelitian [35], menunjukkan bahwa kitosan mampu menekan proses osteoklastogenesis. Osteoklastogenesis tergantung pada interaksi tertutup antara prekursor osteoklas dan sel stromal sumsum tulang. Sel stromal mensekresikan sitokin MCSF (macrophage-colony stimulating factor), yang penting untuk diferensiasi osteoklas dan makrofag dari prekursornya. Sel stromal juga mengekspresikan molekul yang disebut RANKL (receptor activator of nuclear factor K $\beta$ ligand) pada permukaan sel, yang molekul ini nantinya berinteraksi dengan reseptor permukaan sel lainnya yang terdapat pada prekursor osteoklas yang disebut RANK (receptor activator of nuclear factor ${ }_{k} \beta$ ) untuk promosi diferensiasi prekursor osteoklas menjadi osteoklas matang. Interaksi RANK-RANKL dihambat molekul lainnya yang disebut sebagai osteoprotegerin(OPG) dimana berperan sebagai ligand untuk RANK dan dengan aksi ini maka menjadikan aksi inhibitor yang poten dalam pembentukan osteoklas.Hal ini menunjukkan bahwa pada kelompok perlakuan memiki densitas tulang yang paling besar. Nilai densitas tulang pada kelompok perlakuan yang diberi 
Kitosan $45 \mathrm{mg} /$ hari menunjukkan densitas tulang yang paling baik. Hal ini diduga diperankan oleh Kitosan yang mampu meregulasi remodeling tulang. Kitosan secara progresif akan menurunkan produksi prostaglandin E2 [36] dan sitokin inflamatori yaitu IL-1, IL-6 dan TNF- $\alpha$ [37]. Penurunan prostaglandin dan sitokin inflamatori menyebabkan pembentukan dan aktivitas osteoklas terganggu sehingga menurunkan tingkat resorpsi tulang. Selain itu, kitosanjuga dapat meningkatkan formasi dan diferensiasi osteoblas pada proses pembentukan tulang. Kitosan tersebut menunjukkan pengaruh menguntungkan bagi kesehatan tulang [38].

\section{KESIMPULAN}

Pemberian ekstrak serbuk kitosan $45 \mathrm{mg} / \mathrm{KgBB} /$ hari selama 10 hari, dapat menurunkan jumlah Osteoklas dan meningkatkan jumlah Osteoblaspada tikus putih betina model menopause.

\section{Saran}

Perlu penelitian lebih lanjut dengan bermacam-macam dosis untuk menentukan dosis optimal untuk menurunkan jumlah osteoklas dan meningkatkan jumlah osteoblas.Perlu dilakukan penelitian tentang uji toksisitas ekstrak kitosan sebelum digunakan sebagai terapi untuk menurunkan jumlah osteoklas dan meningkatkan jumlah osteoblas pada manusia.Perlu adanya penelitian lebih lanjut tentang bagimana pemanfaatan yang tepat (sediaan, dosis bahan dan tehnik aplikasi), serta lama terapi efektif dari kitosan sebagai terapi osteoporosis pascamenopaus.

\section{DAFTAR PUSTAKA}

1. Malole M, BN, C SU, Pramono, 1989. Penggunaan Hewan-hewan Percobaan Dilaboratorium.Bogor, PAU Bioteknologi IPB.

2. Torres, da Silva, 2011.The influence of Modified Chitosan Subtrates on Osteoclastogenesis. Thesis Fakultas Kedokteran Biomedika Universitas do Porto, p. $18-28$

3. Pascasia L C S, 2008. Fortifikasi Tepung Cangkang Udang Sebagai Sumber Kalsium Pada Mie Basah [skripsi]. Fakultas Perikanan dan Ilmu Kelautan.Bandung, Universitas Padjadjaran.

4. Rivaldi, D. 2011. Pangaruh Pemberian Extract Daun Pegangan (Centella asiatika) Terhadap Kadar Fosfor Dalam Darah Pada Tikus (Rattus Norvegicus) Ovarektomi. Artikel Ilmiah. Surabaya: Fakultas Kedokteran Hewan, Universitas Airlangga.

5. Bertens, APMG, Booij, LHDJ, Flecknell, PA et al, 1993.Anaesthesia, Analgesia and euthanasia. In: Principles of laboratory Animal Sciences. Eds Zutphen, L.F.M., Baumans, V. and Beynen, A.C., pp. 267-298, Amsterdam, Elsevier 
6. Dick IM, Price RL, 2001. The Effect Of Estrogen On Renal Phosporus Handling In The Rat. Nephrol, Am Jaunal21 : 323-330

7. Effendy, at all. 2011.Antibacterial, Radical-Scavenging Activities And Cytotoxicity Properties Of Phaleria Macrocarpa (Scheff.)Boerl. Leaves In Hepg2 Cell Lines. IJPSR, Vol. 2(7): 1700-1706

8. Federer W, 1991.statistic and society :data collection and interpretation. 2nd ed. New York : Marcel Dekker

9. Johnson Delaney C, 1996. Exotic Companion Medicine Handbook for Veterenarians (2 Vol. Set). Lake Worth, FL: Zoological Education Network.

10. Salma dan Yohana Waspada12 Penyakit yang Merusak Tulang Anda. Redaksi Cerdas Sehat. PT. Niaga Swadaya, April 2013.

11. Sularsih, Soeprijanto. 2012. Perbandingan Jumlah Sel Osteoblas pada Penyembuhan Luka Antara Penggunaan Kitosan Gel 1\% dan 2\%.Jurnal Material Kedokteran Gigi. Vol. 1 (1):83-157.

12. Masir, Okky, 2012.Pengaruh Cairan Cultur Filtrate Fibroblast (CFF) Terhadap Penyembuhan Luka; Penelitian eksperimental pada Rattus Norvegicus Galur Wistar.http://jurnal.fk.unand.ac.id. Diakses tanggal 12 Februari 2014 pukul 8.19

13. Morgan G, dan Hamilton C 2009. Panduan Praktik Obstetri dan Ginekologi Buku Kedokteran.Terjemahan oleh Rusi M. Syamsi dan Ramona P. Kapoh. Jakarta:EGC.

14. NurdinS, 2002.Pengaruh Pemberian Tepung, Tahu dan Tempe kedelai Dalam Ransum Terhadap Masa Densitas Tualang Tikus Betina Ovariektomi. [Thesis], Bogor, Pasca Sarjana IPB

15. Nabil ,. 2005. Pemanfaatan Limbah Tualang Ikan Tuna(Thunus sp.) Sebagai Sumber Kalsium Dengan Metode Hidrolisis Protein. [skripsi].Bogor, Fakultas Perikanan dan Ilmu Kelautan, Institut Pertanian Bogor.

16. Honarkar H, and Barikani M, 2009. Application of Biopolymer 1 : Kitosan, Monatsh Chem, $140: 1403-20$

17. Kurniasih, Mardiyah dan Kartika, Dwi, 2011.Sintesis dan Karakterisasi Fisika-Kimia Kitosan.Jurnal Inovasi. Vol. 5 (1):42-48.

18. Mineralisasi Tualang Femur Tikus Menderita Osteodistrofia Fibrosa.[Skripsi].Cirbon,Institud Agama Islam Negeri (IAIN) Steekh Nurjati Cirebon.

19. Rachman IA, 1999. Paparan Sinar UV. Beta Terhadap Remodelling Tulang: Study Eksperiment Pada M.Fascicularis yang Hipoestrogenis. [Disertai]. Program Pasca Sarjana UI. Jakarta.

20. Setyorini, A, Suandi, I Sidiarta, dan Suryawan.2009. Pencegahan Osteoporosis dengan Suplementasi Kalsium dan Vitamin D pada Panggunaan Kortikosteroid Jangka Panjang. Jurnal Sari Pediatri, Vol. 11, No.1.

21. Sondakh, J. Sanger, OMG. \& Masengi, JA. 2001. Perbandingan Kadar Fosfatase Alkali Khas Tulang dan Kalsium Total: pada Wanita Pascamenopause dan Masa Reproduksi. Maj Obstet Ginekol Ind. 25 (3): 187-190.

22. Wiyarsi, Antuni,\& Priyambodo, Erfan. (2009). Pengaruh Konsentrasi Kitosan dari Cangkang Udang terhadap Efisiensi Penjerapan Logam Berat. Fakultas Kimia FMIPA UNY. staff.uny.ac.id/sites/default/files/132312678/Penelitian\%20kitosan.pdf [2 September 2013]

23. Suharjo dan Noor Harini, Ekstraksi Kitosan dari Cangkang Udang Windu

24. (Penaeus Monodon Sp) Secara Fisik - Kimia (Kajian Berdasarkan Ukuran Partikel Tepung Chitn dan Konsentrasi NaOH). Vol.1 no.1, September 2005: 7 - 15 
25. Taber, Benzion. Kapita Selekta Kedaruratan Obstetri dan Ginekologi.Terjemahan oleh Teddy Supriyadi dan Johanes Gunawan. 1994. Jakarta:EGC

26. Honarkar H, and Barikani M, 2009. Application of Biopolymer 1 : Kitosan, Monatsh Chem, $140: 1403-20$

27. Redaksi Cerdas Sehat. 2013. Waspada 12 Penyakit yang Merusak Tulang Anda. Jakarta:Penerbit Cerdas Sehat.

28. Sudoyo, Setiyohadi, Alwi, Simadibrata, dan Setiati. 2009. Buku Ajar Ilmu Penyakit Dalam Jilid III Edisi V. Jakarta Pusat:InternaPublishing.

29. Van Abel, M., J.G.J. Hoendrop, O. Dardenne, R. St Arnaud, C.H. Van Os, H.J.P.T.M. Van Leeuwen, and R.J.M. Bindels. 2002. 1,25-Dihydroxyvitamin D3-Independent Stimulatory Effect of Estrogen On the Expression of ECAC1 In The Kidney. J. Am. Nephrol. 13:2102-2109

30. XuH., JK Uno, M Inouye L Xu, JB, Dress JF Collin, and F.K. Ghishan. 2003. Regulation of Intestinal NaPi-IIb contransporter gene expression by estrogen. J. Am. Physiol. Gastrointest. 285: 1317-1324.

31. Zairin Noor, Moh Hidayat, Agus Hadian Rahim and Sutiman B. Sumitro.Bone Microstructure and Atomic Periodic Disharmonization in Osteoporosis. Unicersa Medicina. Vol. 31 no.2 May - August, 2012.

32. Yildiz A, Hayirli, A, Okumus Z et al. (2007) Physiological profile of juvenile rats: effect of cage size and cage density. Laboratory Animals, 36, 28-38

33. Smeltzer dan Bare, 2002.Keperawatan Medikal Bedah. Volume 1. EGC,Jakarta, hal. 119-120

34. Shor-posner, G, Brennan , G, Ian, C. et al. 1994 Meal Patterns of macronutrient intake in rats with particular dietary preferences. American Journal of Physiology, 266, R1395-402

35. Pusponegoro AD, 2005. Luka Dalam, Buku Ajar Ilmu Bedah. Edisi ke-2. Jakarta: EGC

36. Mawarda P C, R. Triana, Nasrudin, 2011. Funsionalisasi Limbah Cangkang Udang untuk Meningkatkan Kandungan Kalsium susu Kedelai Sebagai Penambah Gizi Masyarakat [Program Kreativitas Mahasiswa, Gagasan Tertulis].Bogor, Institut Pertanian Bogor.

37. American Medical Association, 2004.Phycisians Dedicated to the Health of America, DC: APA, Third Edition. Washington

Sularsih, Soeprijanto. 2012. Perbandingan Jumlah Sel Osteoblas pada Penyembuhan Luka Antara Penggunaan Kitosan Gel 1\% dan 2\%.Jurnal Material Kedokteran Gigi. Vol. 1 (1):83-157.

2009.Histolgi Umum, CV Sagung Seto, Jakarta, p. 106-7, 111.

38. Nurlena, 2005.Tampilan Kalsium Dan Fosfor Darah, Produksi Susu, Ion Kalium dan Jumlah Bakteri Susu Sapi Perah FriesiannHolstein Akibat Pemberian Aras Sauropus androginus (L) Mer (Katu). [Thesis].Semarang, Pasca Sarjana Universitas Diponegoro. 